\title{
Water erosion associated with rainfall patterns in the extreme South of Bahia in eucalyptus post-planting
}

\section{Erosão hídrica associada a padrões de chuva no extremo Sul da Bahia em pós-plantio de eucalipto}

\author{
Danielle Vieira Guimarães ${ }^{1 *}$; Marx Leandro Naves Silva ${ }^{2}$; Diêgo Faustolo \\ Alves Bispo ${ }^{3}$; Sérgio Gualberto Martins ${ }^{4}$; José de Oliveira Melo Neto ${ }^{5}$; Ricardo \\ Previdente Martins ${ }^{6}$; Nilton Curi ${ }^{2}$
}

\begin{abstract}
Soil and water losses caused by water erosion represent a risk of environmental damage and loss of soil productivity, with economic, social and environmental consequences. Plant cover is an important ally against water erosion, together with the knowledge of rainfall characteristics. Thus, this study aimed to evaluate the soil and water losses and to determine rainfall patterns in two homogeneous eucalyptus plantations; one in Yellow Argisol, located in Teixeira de Freitas, and another in Humiluvic Spodosol, located in Caravelas, both in the Extreme South of the state of Bahia. Erosion plots were installed, and consisted of three treatments: bare soil, eucalyptus, and native forest. Rainfall data was obtained from an automatic gauging station, with 10 minute registration interval for erosivity (erosivity index $\mathrm{EI}_{30}$ ) and rainfall pattern analyses. Higher soil losses were observed in Yellow Argisol, and the advanced rainfall pattern was predominant. Eucalyptus minimum tillage was efficient in reducing soil and water losses by water erosion.
\end{abstract}

Key words: Soil losses. Rainfall erosivity. Planted forest.

\section{Resumo}

As perdas de solo e de água por erosão hídrica representam risco de dano ambiental e redução da produtividade dos solos, sendo uma das principais formas de degradação com consequências econômicas, sociais e ambientais. A cobertura vegetal é um importante aliado no combate à erosão hídrica, assim como o conhecimento das características da chuva. Deste modo, o presente estudo teve como objetivo avaliar as perdas de solo e água e determinar os padrões de chuva em floresta homogênea de eucalipto em Argissolo Amarelo, no município de Teixeira de Freitas, e em Espodossolo Humilúvico, no município de Caravelas, ambas no Extremo Sul da Bahia. Parcelas de perdas de solo foram instaladas envolvendo três tratamentos: solo descoberto, Eucalipto e Mata nativa (área em equilíbrio), em ambas as classes de solo avaliadas. Para a erosividade, obtida pelo índice de erosividade em 30 minutos $\left(\mathrm{EI}_{30}\right)$, e para os padrões de chuva dos eventos erosivos foram considerados dados pluviométricos obtidos em estação

1 Enga Florestal, M.e em Ciência do Solo, Universidade Federal de Lavras, UFLA, Lavras, MG, Brasil. E-mail: danyvguimaraes@ hotmail.com

2 Prof. Titular, Departamento de Ciência do Solo, UFLA, Lavras, MG, Brasil. E-mail: marx@dcs.ufla.br; niltcuri@dcs.ufla.br

3 Dr. em Ciência do Solo, UFLA, Lavras, MG, Brasil. E-mail: diegofaustolo@gmail.com

4 Prof. Adjunto, Departamento de Zootecnia, Universidade Federal de São João del-Rei, UFSJ, São João del Rei, MG, Brasil. E-mail: sergiogualberto@ufsj.edu.br

5 Dr. em Recursos Hídricos em Sistemas Agrícolas, UFLA, Lavras, MG, Brasil. E-mail: joseneto_86@hotmail.com

6 Eng $^{\circ}$ Agr ${ }^{\circ}$, UFLA, Lavras, MG, Brasil. E-mail: rickprev@yahoo.com.br

"Author for correspondence

Received: Nov. 29, 2016 Approved: May 18, 2017 
climatológica automatizada, com intervalos de registro de 10 minutos. As maiores perdas de solo foram observadas no Argissolo Amarelo e o padrão de chuva predominante foi o avançado. O cultivo mínimo de eucalipto mostrou-se eficiente na redução das perdas de solo e de água por erosão hídrica.

Palavras-chave: Perdas de solo. Erosividade da chuva. Floresta plantada.

\section{Introduction}

Erosive processes are one of the major negative impacts silvicultural activities can cause. These processes are intensified when forest plantations are established in former agricultural areas. This is a common practice in Brazil, especially in areas already impacted by anthropic activities (CÂNDIDO et al., 2015; PINHEIRO et al., 2013).

Soil losses due to erosion represent risks of environmental degradation, potential damage to crop yield due to the removal of the richest layers of soil organic matter (SOM), sedimentation, and contamination of water bodies (CARDOSO et al., 2012; OLIVEIRA et al., 2014; RIBEIRO et al., 2016). Based on this premise, conservation practices are fundamental to reduce or mitigate erosion effects.

In eucalyptus plantations implanted with conservation practices, soil losses are much lower than those implanted with non-conservationist systems, as reported by Silva et al. (2011). The authors observed $80 \%$ reduction in soil losses in a Red-Yellow Latosol due to the crop residues in the area, and $88 \%$ reduction in soil losses in a system where eucalyptus plantation was contour-planted.

Rainfall stands out among the factor that causes water erosion, since it can disaggregate and transport soil particles (ROSA et al., 2016). Rainfall erosivity is one of the most difficult factors to predict and control, and is defined as the potential of rainfall to cause erosion by the detachment and transport of soil particles. However, erosivity depends on basic physical characteristics, such as the size, shape and speed of raindrops when they reach the ground (AQUINO et al., 2013).
Characteristics of rainfall events, such as intensity and duration, are also important in studies on water erosion (TRINDADE et al., 2016). The highest intensity peak of the rainfall event defines the rainfall patterns, and can cause more or less erosion. This fact explains the importance of characterizing these patterns by region, classifying them as advanced, intermediate or delayed (ELTZ et al., 2013).

Most of the studies carried out in Brazil involving rainfall patterns and their relationship with water erosion use rainfall simulators, which makes it difficult to extrapolate the data to natural conditions (WANG et al., 2016). Thus, further studies under natural rainfall conditions are fundamental. Aquino et al. (2013), seeking to relate soil losses with rainfall patterns in Haplic Cambisol and Red Latosol in the south of the state of Minas Gerais, observed higher soil losses by rainfall event associated with the advanced pattern. Similarly, Wang et al. (2016), in a study carried out in Beijing, identified that the advanced pattern was related to 55 to $68 \%$ of soil losses. In Brazil, many studies have also observed a predominance of erosive events classified as advanced (BAZZANO et al., 2010; CASSOL et al., 2007; MAZURANA et al., 2009).

In the extreme south of Bahia, eucalyptus plantation has increasingly expanded both due to the climatic characteristics of the region and to the typical soils of the Coastal Tablelands. The smooth dominated relief of the region favors mechanized silviculture. However, due to the very low permeability of these soils, a small slope of the terrain (> $3 \%$ slope) is sufficient to promote substantial erosion losses (RESENDE et al., 2014). The lack of studies on rainfall erosivity 
and the occurrence of water erosion in this region hinder the conservationist planning of land use (OLIVEIRA et al., 2013b). Anache et al. (2017) point out the importance of new studies on soil losses in Brazil for the improvement of soil and water conservation techniques. The objective of this study was to quantify soil and water losses and to determine the rainfall patterns in eucalyptus forest in a Yellow Argisol and Humiluvic Spodosol, in the municipalities of Teixeira de Freitas and Caravelas, respectively, in the extreme south of Bahia.

\section{Material and Methods}

The study was carried out in the extreme south of the state of Bahia, in the municipalities of Teixeira de Freitas and Caravelas (Figure 1), between October 2012 and October 2014, and between August 2012 and August 2014, respectively. The region is classified as type Af climate, according to the Köppen, characterized by hot and humid tropical climate, with average monthly temperatures above $22^{\circ} \mathrm{C}$, and total annual rainfall varying from 1300 to $1600 \mathrm{~mm}$ (ALVARES et al., 2013).

Figure 1. Location of homogeneous Eucalyptus plantations in the extreme south of Bahia, in the municipalities of Caravelas and Teixeira de Freitas.

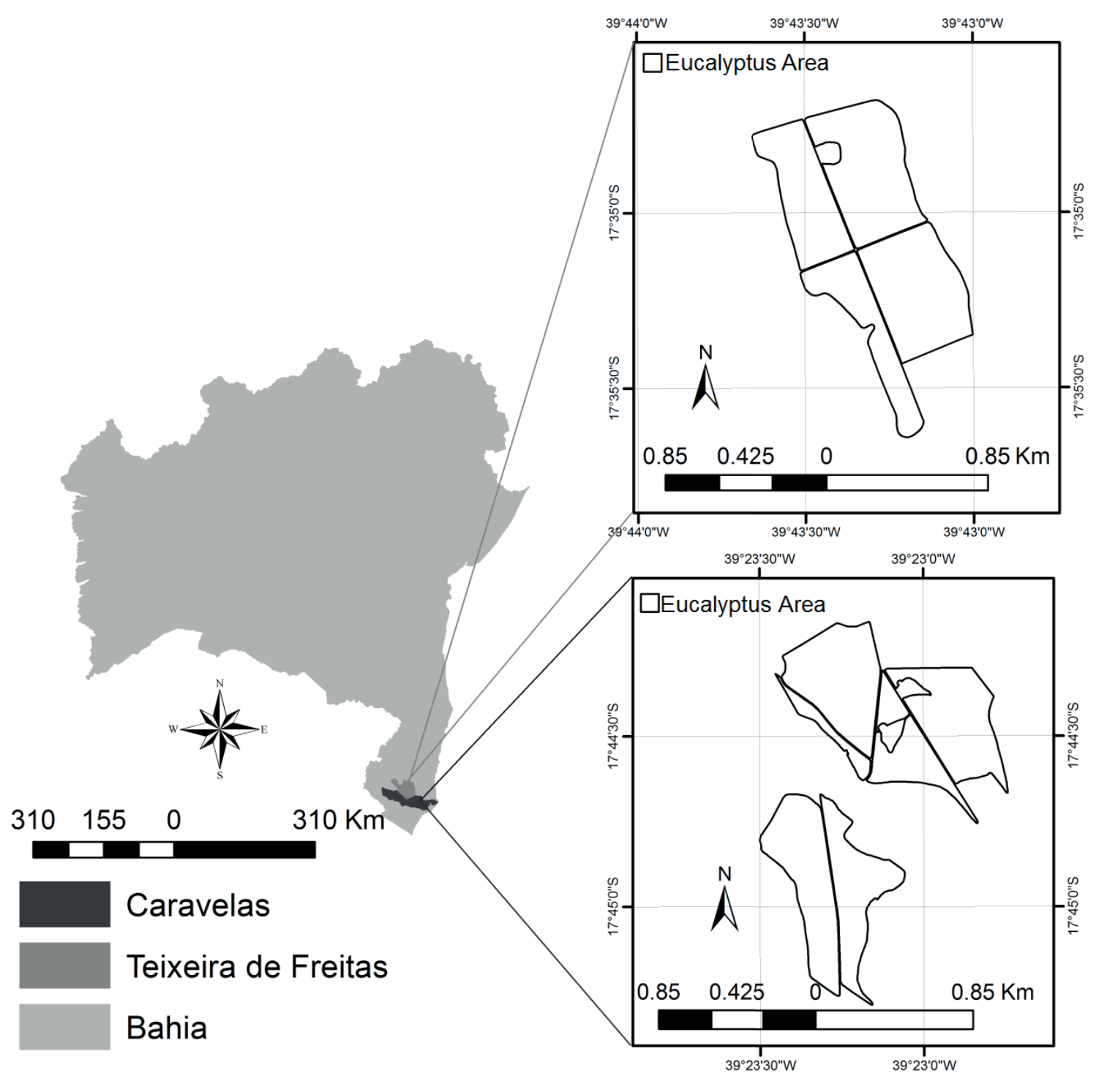


The soils are typical of the Coastal Tablelands and were classified according to the Brazilian Soil Classification System (EMBRAPA, 2013) as: Abruptic Dystrocohesive Yellow Argisol, in Teixeira de Freitas, and Typical Orthic Humiluvic Spodosol, in Caravelas. Granulometric fractions of the soils were determined by the densimeter method, and soil organic matter was determined by wet combustion (EMBRAPA, 1997), as shown in Table 1.

The study area was previously occupied by planted pasture. From the eucalyptus implantation to the period when the present study was carried out, four crop cycles were performed in the system of minimum cultivation and preparation of the soil in the planting row at $60 \mathrm{~cm}$ depth, with the presence of residues from the previous harvest cycle in the field. First, the area was desiccated with glyphosate, the same herbicide used inter-rows at three and 12 months after planting. Harvester and Forwarder were used in the harvests; wood was peeled in the field; and the residue was maintained on the soil. The clone used was a hybrid of $E$. grandis x $E$. urophylla. Planting was carried out in August 2012, in Teixeira de Freitas, where erosion plots were also installed, and in November 2011, in Caravelas. However, in the Caravelas, the erosion plots were implanted in August 2012.

Table 1. Granulometric fractions and soil organic matter (SOM) of Yellow Argisol, located in the municipality of Teixeira de Freitas, and of Humiluvic Spodosol, located in the municipality of Caravelas, both in an area under native forest in the extreme south of Bahia.

\begin{tabular}{|c|c|c|c|c|c|c|c|c|}
\hline Depth & Clay & Silt & VCS & $\mathrm{CS}$ & MS & FS & VFS & $\mathrm{SOM}$ \\
\hline \multirow[t]{2}{*}{$\mathrm{cm}$} & \multicolumn{7}{|c|}{ 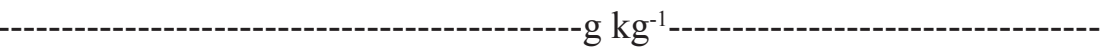 } & $\%$ \\
\hline & \multicolumn{8}{|c|}{ Abruptic Dystrocohesive Yellow Argisol } \\
\hline $0-10$ & 170 & 60 & 150 & 210 & 220 & 160 & 30 & 3,29 \\
\hline $10-20$ & 200 & 60 & 130 & 180 & 200 & 190 & 40 & 1,60 \\
\hline \multirow[t]{2}{*}{$20-40$} & 240 & 40 & 130 & 170 & 200 & 180 & 40 & 1,22 \\
\hline & \multicolumn{8}{|c|}{ Typical Orthic Humiluvic Spodosol } \\
\hline $0-10$ & 230 & 40 & 70 & 230 & 230 & 170 & 30 & 2,43 \\
\hline $10-20$ & 230 & 60 & 70 & 200 & 210 & 190 & 40 & 2,08 \\
\hline $20-40$ & 250 & 50 & 60 & 170 & 200 & 210 & 60 & 1,11 \\
\hline
\end{tabular}

VCS: very coarse sand; CS: coarse sand; MS: medium sand; FS: Fine sand; VFS: very fine sand; SOM: soil organic matter.

To determine soil and water losses, three treatments were considered in each soil type: Eucalyptus minimum tillage; bare soil; and native forest(equilibrium), which corresponds to a fragment of the Semidecidual Seasonal Forest, a secondary forest at intermediate stage of regeneration, with canopy and understory formation, located at the margin of the eucalyptus stands, with 96 ha in the Argisol area and 34 ha in the Spodosol area.
Erosion plots ( $4 \times 24 \mathrm{~m}$ ) were installed on 4 and 9\% slopes in Spodosol and Argisol, respectively. In the areas with eucalyptus, erosion plots were installed considering row and inter-row in each plot, as shown in Figure 2. Bare plots were installed in areas formerly occupied by planted pasture, which were later planted with eucalyptus for four crop cycles, with no other planting after the fourth harvest, and the entire cover of the soil was removed, including the crop residues, corresponding to a 
carrier area. Vegetation control was performed with costal herbicide and/or mowing. The area of the immediate border of the fragment was avoided for the installation of the plot.

The gutter installed at the end of each plot leads the runoff water to the $250 \mathrm{~L}$ tank with a Geib splitter with 15 windows, which allows that only 1/15 of excess runoff pass to a second $500 \mathrm{~L}$ tank.
Slide height readings and sediment collection in the tanks were performed after each rainfall event. The material was sent to the laboratory, where the sediment was decanted, oven dried, and weighed in a scale with $0.01 \mathrm{~g}$ accuracy. The data obtained in the laboratory were used to calculate the soil and water losses, following the procedure described by Cogo (1978).

Figure 2. Scheme of the soil loss plots installed in the areas with eucalyptus minimum tillage, in Caravelas and Teixeira de Freitas, in the extreme south of Bahia.

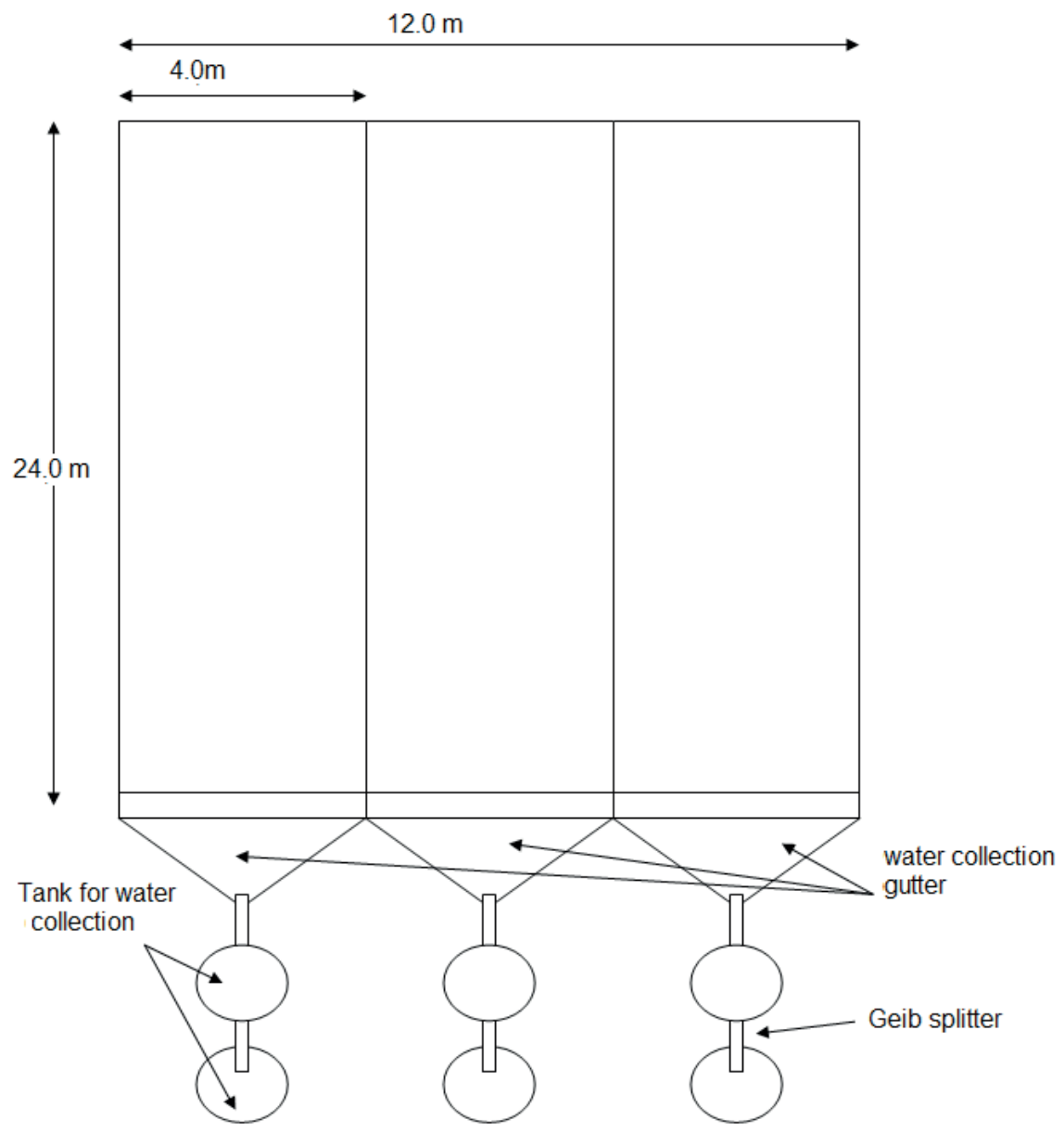

Rainfall data were used to calculate erosivity, with 10-minute recording intervals, obtained in an automated climatological station belonging to the Suzano Papel \& Celulose Company. Individual rainstorm events were identified as those separated from each other by a minimum of six hours (CABEDA, 1976), and those with events with more than $10 \mathrm{~mm}$ precipitation or with kinetic energy greater than 3.6 $\mathrm{MJ} \mathrm{ha}^{-1}$ were considered as erosive (WISCHMEIER; SMITH, 1978). 
The rain kinetic energy was determinate by the equation proposed by Wischmeier and Smith (1978), as shown in Equation 1:

$$
\mathrm{Ke}=0.119+0.0873 \log \mathrm{I}
$$

where:

$\mathrm{Ke}=$ kinetic energy $\left(\mathrm{MJ} \mathrm{ha}^{-1} \mathrm{~mm}^{-1}\right)$;

$\mathrm{I}=$ rainfall intensity $\left(\mathrm{mm} \mathrm{h}^{-1}\right)$.

To obtain $\mathrm{Ke}$ in $\mathrm{MJ} \mathrm{ha}^{-1}$, the result found with Equation 1 was multiplied by the rainfall event in millimeters. The $\mathrm{EI}_{30}$ index was calculated using Equation 2:

$$
\mathrm{EI}_{30}=\mathrm{ke} * \mathrm{I}_{30}
$$

where:

$\mathrm{EI}_{30}=$ Rainfall erosivity index $\left(\mathrm{MJ} \mathrm{mm} \mathrm{ha} \mathrm{m}^{-1} \mathrm{~h}^{-1}\right)$;

$\mathrm{Ke}=$ kinetic energy $\left(\mathrm{MJ} \mathrm{ha}^{-1}\right)$;

$\mathrm{I}_{30}=$ Maximum intensity in a period of 30 consecutive minutes $\left(\mathrm{mm} \mathrm{h}^{-1}\right)$.

After separating the erosive events, rainfall patterns were defined, according to the Horner and Jens (1942) as following: (i) advanced pattern corresponds to the erosive event in which the peak of the greatest intensity occurs in the first third of the duration of the event, or until $30 \%$ of the total duration; (ii) intermediate pattern shows a higher peak in the second third (between 30 and 60\%); and (iii) delayed pattern has its peak in the third third (after $60 \%$ ) of the duration of the event.

To associate soil losses with the rainfall patterns of each municipality, only the plot without vegetation cover, which presented associated erosive event, was considered in the study.

Wood mean annual increment (WAI) of the population was also considered in the present study, which was made available by the company Suzano Papel and Celulose, since soil losses by water erosion can cause reduction of crop productivity (MARTINS et al., 2010), influencing WAI.

\section{Results and Discussion}

Soil and water losses in Argisol were high when only the effect of the soil type was considered, corresponding to the plot without vegetation cover (Table 2). The characteristics of each soil confer greater or lesser resistance to water erosion, and typify the behavior of each exposed soil when under similar conditions of rainfall, topography and vegetation (BERTONI; LOMBARDI NETO, 2012).

Table 2. Soil and water losses in Yellow Argisol, located in the municipality of Teixeira de Freitas, and in Humiluvic

\begin{tabular}{|c|c|c|}
\hline Treatment & Soil losses & Water losses \\
\hline & $\mathrm{Mg} \mathrm{ha}^{-1}$ & $\mathrm{~mm}$ \\
\hline & \multicolumn{2}{|c|}{ Yellow Argisol } \\
\hline Eucalyptus minimum tillage & 0.10 & 13.26 \\
\hline Bare Soil & 686.73 & 973.27 \\
\hline \multirow[t]{2}{*}{ Native Forest } & 0.02 & 34.98 \\
\hline & \multicolumn{2}{|c|}{ Humiluvic Spodosol } \\
\hline Eucalyptus minimum tillage & 0.08 & 8.44 \\
\hline Bare Soil & 0.31 & 21.22 \\
\hline Native Forest & 0.03 & 3.70 \\
\hline
\end{tabular}
Spodosol, located in the municipality of Caravelas, Extreme South of Bahia.

Periods from October, 2012 to October, 2014 in Teixeira de Freitas, and from August, 2012 to August, 2014 in Caravelas. 
The presence of an abrupt textural gradient and the high cohesion, characteristic of the cohesive Argisol, hinder water infiltration in the Bt horizon, favoring lateral flow and soil losses. According to Valladares et al. (2012), in Argisol, water infiltration speed tends to reduce on the subsurface layer with higher clay concentration, contributing to higher erodibility of this type of soil. The high subsurface cohesion of this soil corroborates this statement, and the abrupt character helps explain the data obtained in this work.

In addition, the plots in these soils are at 9\% slope, which may favor the erosive process. It is known that the larger the gradient, the greater is the kinetic energy of the runoff. Resende et al. (2014) mention that in Dystrocohesive Yellow Argisol, a small increase in the slope can increase soil loss in these soils due to the low permeability in the $\mathrm{B}$ horizon, coupled with the typical high rainfall of the extreme south of Bahia (1300-1600 mm) (ALVARES et al., 2013).

A recent study carried out by Cândido et al. (2014), which evaluated soil losses in homogeneous eucalyptus forest, showed the importance of adopting conservationist practices in slopes.

Soil losses in the Eucalyptus minimum tillage, bare soil, and native forest areas followed the order: $0.052 ; 343.37$; and $0.011 \mathrm{Mg} \mathrm{ha}^{-1}$ year $^{-1}$, respectively. Martins et al. (2010), in a study on soil losses in homogeneous eucalyptus cultivation systems in Coastal Tablelands soils determined the tolerance of soil losses of Yellow Argisol as 10 $\mathrm{Mg} \mathrm{ha}^{-1}$ year $^{-1}$, which is much higher than the soil losses observed in the present study, except in the area with no vegetation cover. These results confirm the efficiency of Eucalyptus minimum tillage in mitigating the erosive processes, and reinforce the adoption of the minimum tillage as a strategy to ensure the adequate soil management system, especially at the initial stage of the crop, when the plant does not have enough canopy area to intercept the direct impact of rain drops and reduce erosion efficiently.

In the Spodosol area, low soil losses were observed even in the plot without vegetation cover (Table 2). The lower slope in Spodosol plots (4\%) and the occurrence of this type of soil in more concave portions of the landscape contributed to reduced soil and water losses (CURI; KER, 2004) (Figure 3). Carvalho Filho et al. (2013) studied the silvicultural aptitude of the Brazilian Coastal Tablelands for eucalyptus and showed that, in general, slope and slope shape are very important. 
Figure 3. Distribution and location in the landscape of the Brazilian Coastal Tablelands of the South of Bahia.

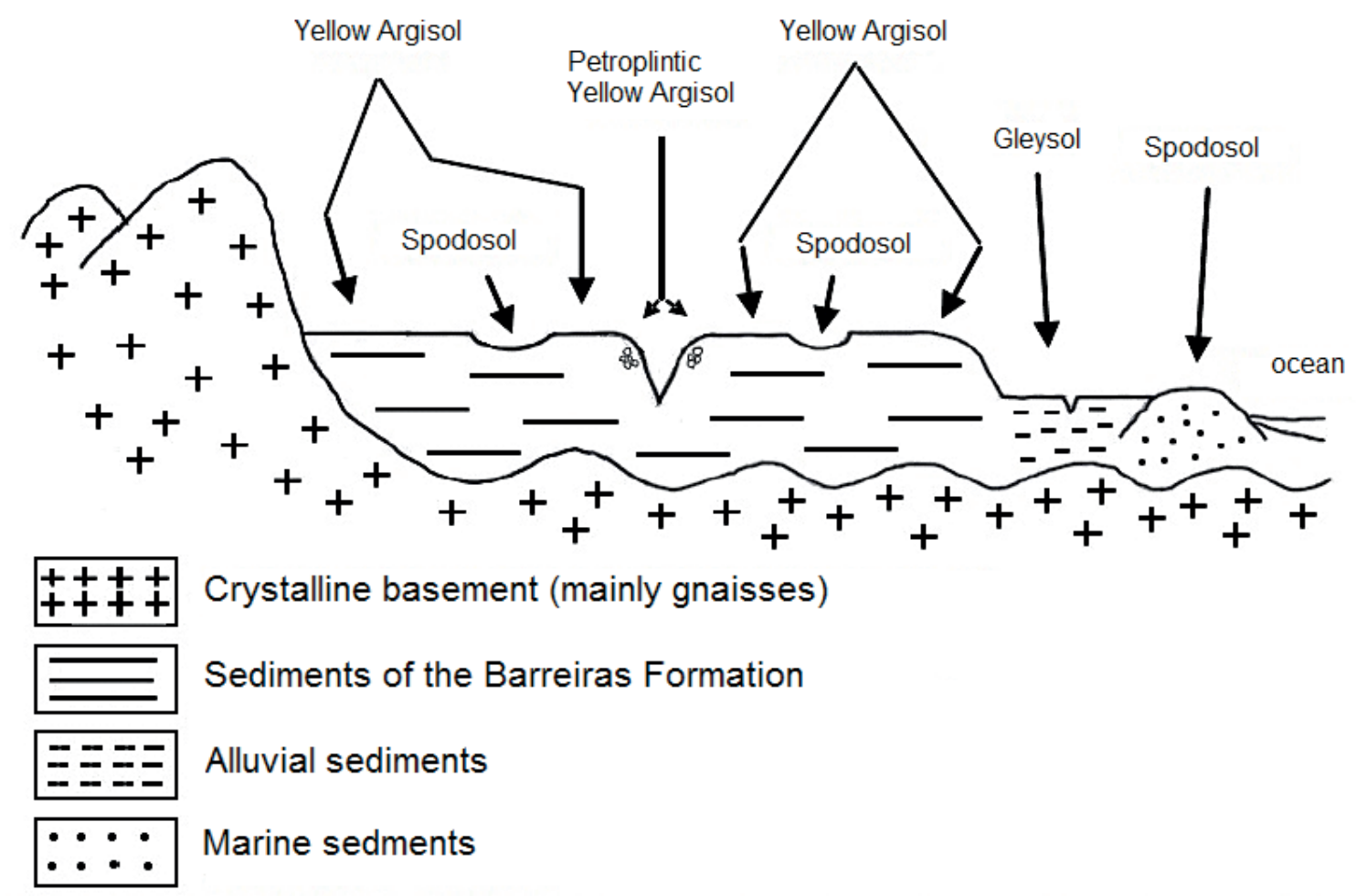

Source: Adapted from Curi and Ker (2004).

Soil losses in the Spodosol area were of 0.04, 0.15 , and $0.015 \mathrm{Mg} \mathrm{ha}{ }^{-1}$ year ${ }^{-1}$ for Eucalyptus minimum tillage, bare soil, and native forest, respectively. Soil loss tolerance for the Spodosol, as determined by Mannigel et al. (2002) in the state of São Paulo, is of $7.79 \mathrm{Mg} \mathrm{ha}^{-1}$ year ${ }^{-1}$. Thus, soil losses observed in this work were substantially lower than the tolerance.

Vegetation cover is another relevant factor for the reduction of water erosion. Table 2 and Figures 4 and 5 show higher soil losses, regardless of the soil type, when the soil presents no vegetation cover.

The absence of vegetation favors the erosive process by exposing the soil to the direct and disintegrating impact of the raindrop. Eucalyptus plantation in the Argisol protected the soil and reduced losses, representing only $0.015 \%$ of the total loss by the bare soil, whereas in Spodosol, such losses represented $26.8 \%$ of the total loss. In the latter case, soil losses were low for all treatments (Table 2). By observing that soil and water losses were lower than those of the bare plot for both studied soils, it is possible to state that the Eucalyptus minimum tillage system, even in the first two years after planting, was efficient in reducing erosion. Also, soil losses in this crop were similar to those of native forest. These facts indicate the sustainability of this silvicultural exploitation and the efficiency of the maintenance of litter to reduce soil and water losses. Oliveira et al. (2013a) studied erosion in forest systems and reported that not only the species, but also the age of the plant directly influence soil erosion losses. 
Figure 4. Soil losses in Argisol, in the municipality of Teixeira de Freitas (BA), from October 2012 to October 2014.

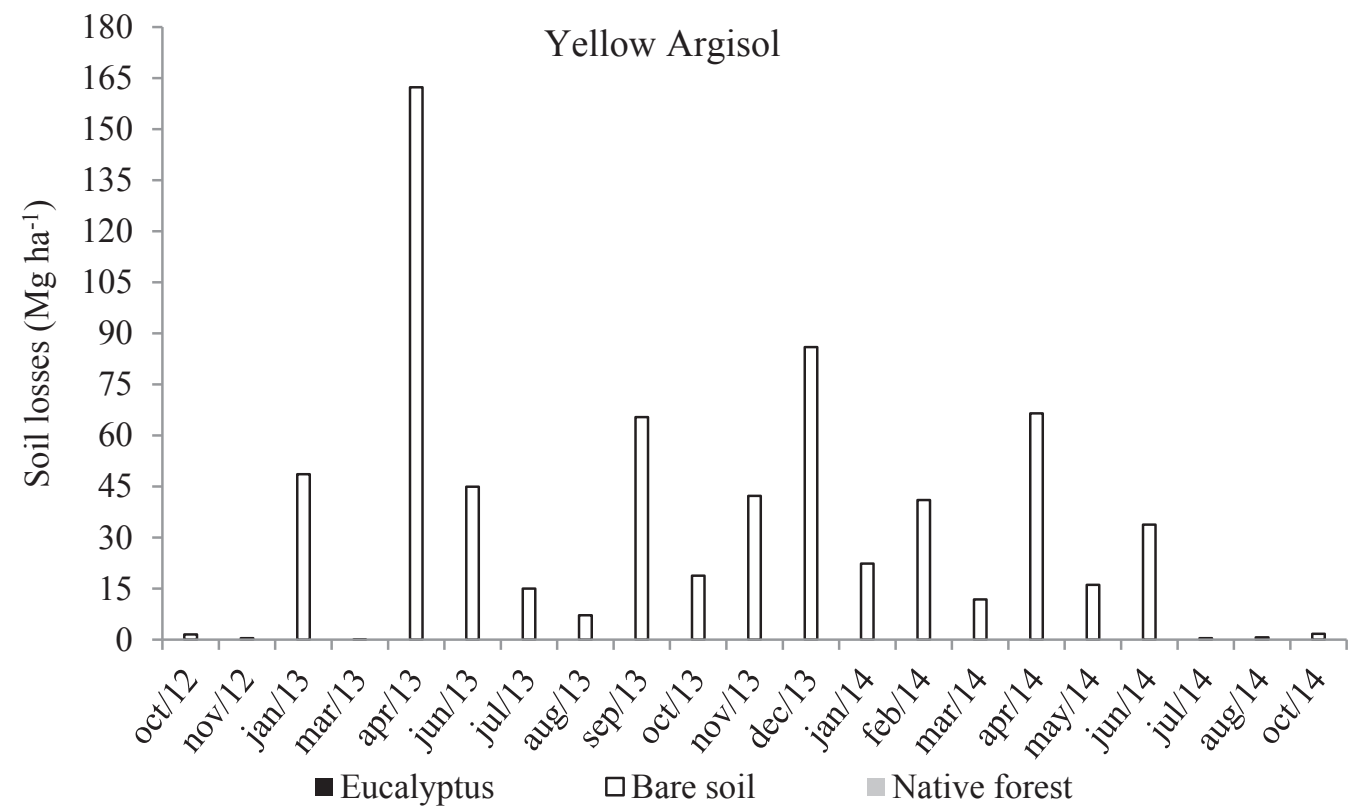

Figure 5. Soil losses in Spodosol, in the municipality of Caravelas (BA), from August 2012 to August 2014.

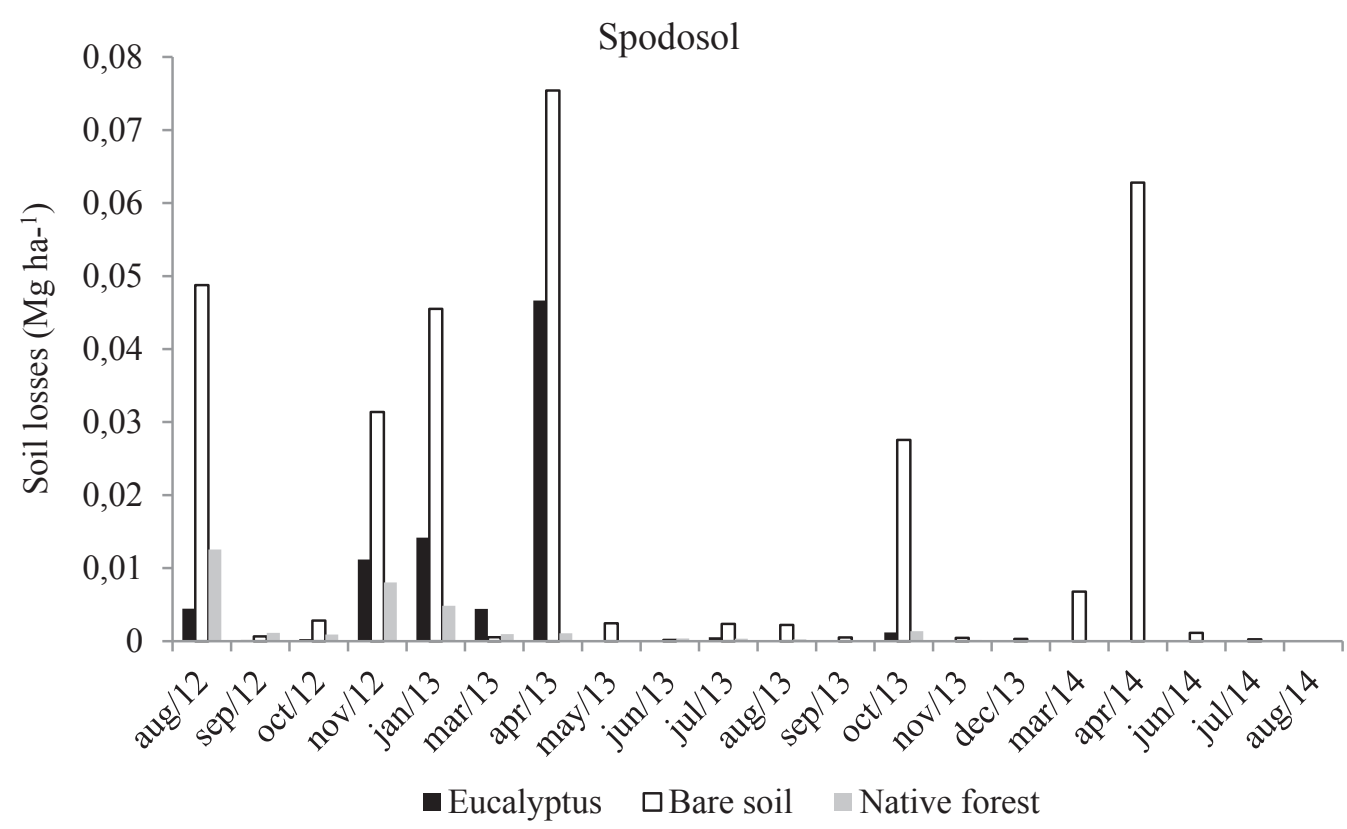

The native forest plot conferred better soil protection in all situations, which can be proved by the lower rates of soil loss (Table 2). The absence of anthropogenic interference in this plot guarantees the balance of the environment, and the dense vegetation favors the interception of the raindrop and reduces the kinetic energy. 
Mean erosivity was 352.79 and 408.20 MJ mean erosivity observed in Caravelas, soil and $\mathrm{mm} \mathrm{ha}^{-1} \mathrm{~h}^{-1}$ month $^{-1}$; mean rainfall was 98.97 and $97.84 \mathrm{~mm}$; and total rainfall was $2474.18 \mathrm{~mm}$ and $2445.94 \mathrm{~mm}$ for Teixeira de Freitas and Caravelas, respectively (Figures 6 and 7). Despite the higher water losses were much lower than those of Teixeira de Freitas (Table 2), which reinforces the influence of soil class, landscape position, slope shape, and slope gradient on water erosion.

Figure 6. Rainfall and erosivity in the municipality of Teixeira de Freitas, in the extreme south of Bahia.

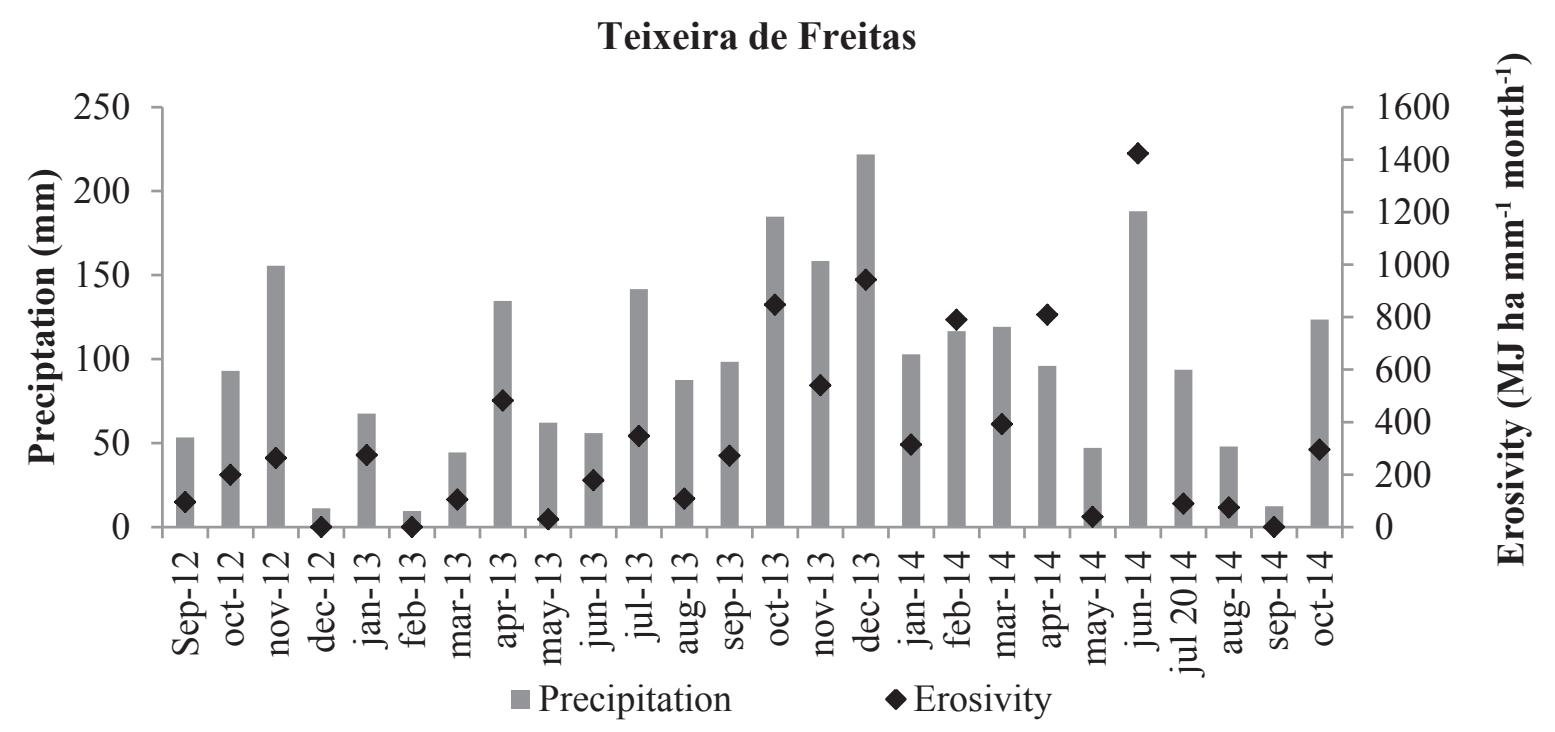

Figure 7. Rainfall and erosivity in the municipality of Caravelas, in the extreme south of Bahia.

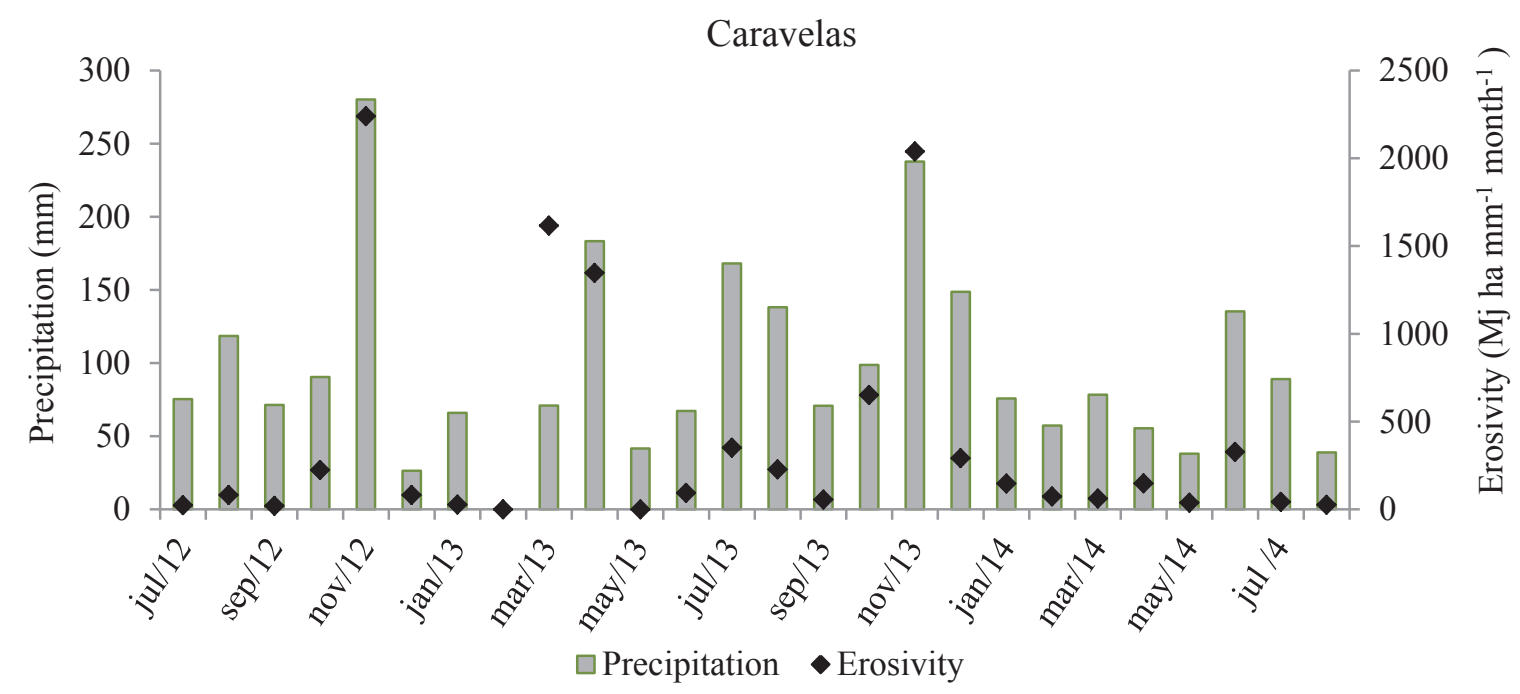


In April 2013, the greatest soil loss was observed in the plot without vegetation cover, in both municipalities. The erosivity of this month was 482.23 and $1346.90 \mathrm{MJ} \mathrm{mm} \mathrm{ha}{ }^{-1} \mathrm{~h}^{-1}$ month $^{-1}$ for Teixeira de Freitas and Caravelas, respectively. These values are above the monthly average for the period evaluated, which, together with the absence of vegetation cover, resulted in significant soil loss when compared with the other months.

Water losses due to surface runoff (Table 2) had similar behavior to that reported for soil losses for both soils. In the Argisol, $0.53,39.34$ and $1.41 \%$ of the total rainfall in the evaluated period was lost by surface runoff, in the plots with eucalyptus, bare soil, and native forest, respectively. Slightly higher losses were observed in the plot with native forest, when compared with the eucalyptus plot, which can occur due to the implantation of the plots in the native forest, substantially disturbing the natural balance of the plot (SPERANDIO et al., 2012).

The absence of vegetation cover was critical in the maintenance of soil water, emphasizing the importance of vegetation in infiltration and storage of water. Vegetation cover increases water infiltration rate in the soil and intercepts the direct impact of the raindrop, dissipating its energy and avoiding surface sealing (VALIM et al., 2016). In Spodosol, surface runoff had the same magnitude as that of soil losses, with $0.34,0.86$ and $0.15 \%$ of the total rainfall in the period (Table 2) for eucalyptus, bare soil, and native forest, respectively, reflecting the environmental conditions of the soil.

Wood mean annual increment (with and without bark) observed in the eucalyptus of the Argisol was lower than that of the Spodosol under the same system (Table 3). These values reveal the influence of soil and water losses on crop productivity, since the greatest nutrient exporter system tends to present lower yield due to the higher water erosion in the Argisol. These results corroborate the data obtained by Martins et al. (2010) in the Coastal Tablelands of Espírito Santo.

Table 3. Wood mean annual increment (with and without bark) for two eucalyptus plantantions in the extreme south of Bahia, in Yellow Argisol and Humiluvic Spodosol.

\begin{tabular}{|c|c|c|}
\hline Soil & WAI (with bark) & WAI (without bark) \\
\hline & \multicolumn{2}{|c|}{ 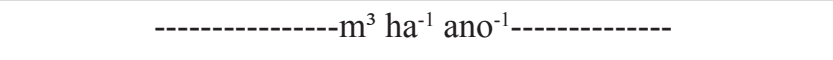 } \\
\hline Yellow Argisol & 27.90 & 23.31 \\
\hline Humiluvic Spodosol & 59.63 & 51.26 \\
\hline
\end{tabular}

In relation to rainfall patterns, the advanced pattern was observed in greater proportion in both areas, followed by the delayed and by the intermediate patterns (Figure 8). For Eltz et al. (2013), advanced rainfall pattern tends to cause lower soil losses since surface sealing, particle disintegration, and particles transport are reduced at the beginning of the rainfall event, when compared with the other patterns.
Results obtained in Teixeira de Freitas (Figure 9) show that soil losses were more directly associated with the advanced rainfall pattern. Of the erosive events that caused soil losses, 16 were classified as advanced, 7 as intermediate, and 12 as delayed; the advanced pattern accounted for $58.7 \%$ of the total soil losses, the intermediate accounted for $13.5 \%$; and the delayed, for $27.8 \%$. On the other hand, $40.3 \%$ of the total water lost by superficial runoff 
was associated with the advanced pattern, and $35.7 \%$ was associated with the delayed pattern. Similarly, Wang et al. (2016), when comparing soil losses and rainfall patterns in China, observed that $68 \%$ of the losses were associated with the advanced pattern, explained due to the shorter duration and greater erosivity of the events.

Figure 8. Rainfall patterns for the municipalities of Caravelas and Teixeira de Freitas, in the extreme south of Bahia.

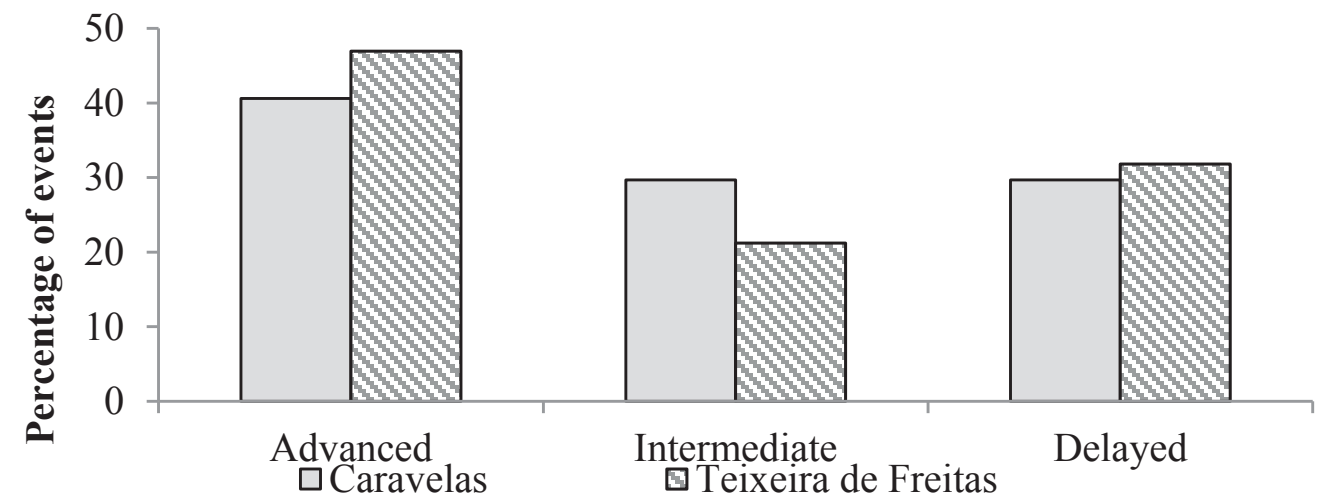

Figure 9. Correlation between rainfall patterns and soil losses in Teixeira de Freitas, in the extreme south of Bahia.

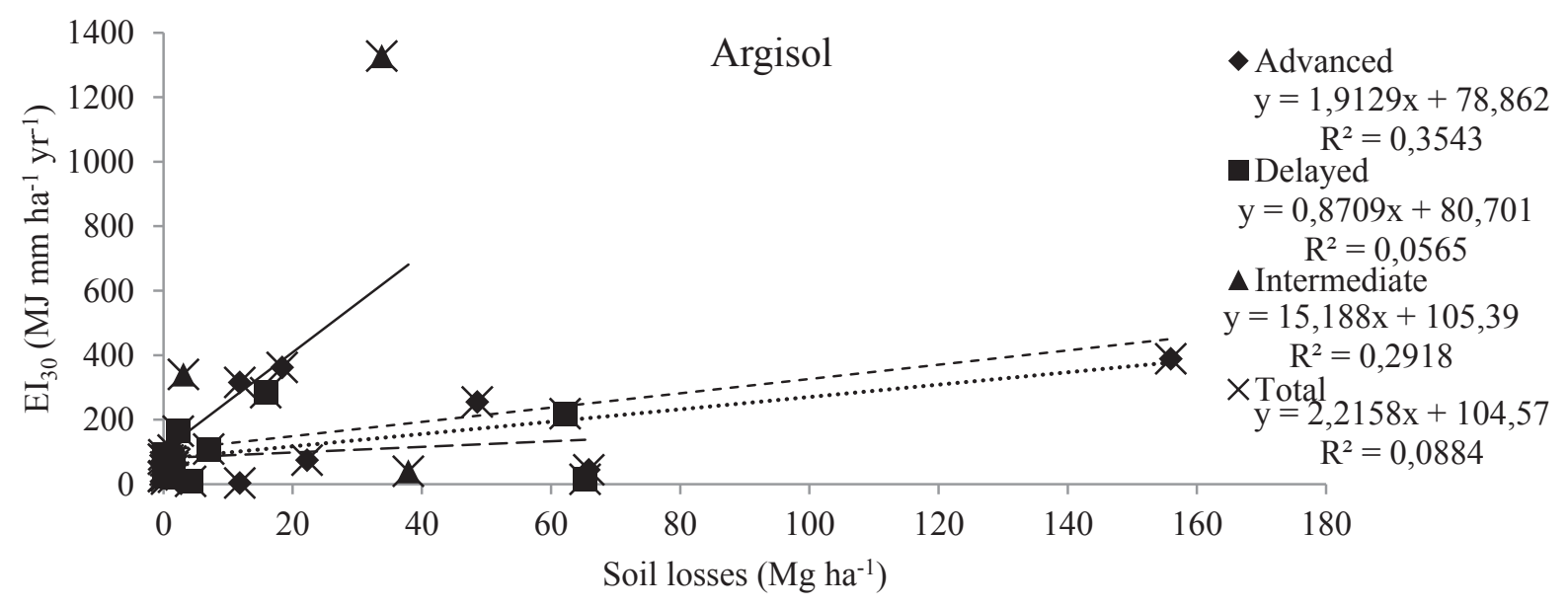

For Teixeira de Freitas, higher coefficient of correlation is observed between soil losses and erosivity for the advanced rainfall pattern $\left(r^{2}=0.35\right)$, being even higher than $\mathrm{r}^{2}$ when the patterns are not distinguished, which is represented in the graph as "Total" $\left(\mathrm{r}^{2}=0.08\right)$. Thus, for higher erosivity, higher soil loss is expected for this rainfall pattern. However, when erosivity is similar between events with different patterns, the advanced pattern caused the least soil loss (Table 4).

In Table 3, when comparing the advanced and delayed patterns for similar erosivity, the latter is related to soil losses higher than those associated with the advanced pattern, except in the second comparative pair, In the second pair, the greater cumulative rainfall of the last five days (P5 days) may have contributed to higher soil loss. This happened 
because the system was already moisturized before the advanced event occurred. Thus, the system may have reached saturation more quickly, making the peak effect at the beginning of the event similar to the effect of the delayed pattern.

Therefore, the antecedent soil moisture was of great importance for the studies on rainfall pattern associated with soil and water losses, corroborating the study developed by Aquino et al. (2013).

Data show that when the rainfall of the last five days is high for the events with advanced pattern, the losses are also high. However, when the event is not influenced by the previous period, i.e., when the soil is dry, comparing the three rainfall patterns with similar erosivity, the advanced pattern causes less losses.
In Caravelas, similar behavior was observed in relation to the occurrence of rainfall patterns, and out of the 22 soil and water loss data associated with rainfall patterns, 11 were related to the advanced rainfall pattern, 6 with the intermediate pattern, and 5 with the delayed pattern. The advanced pattern accounted for $50.6 \%$ of total soil losses, while the delayed pattern accounted for $46.8 \%$ of soil losses (Figure 10). For surface runoff, $70.7 \%$ of the total water loss is associated with the advanced pattern, and $25.7 \%$ with the delayed pattern. It should be considered that losses in the Spodosol area were very low, which hindered the interpretation of the rainfall patterns associated with the losses by water erosion.

Table 4. Characteristics of rainfall events with similar erosivity, and soil and water losses associated with them, in the municipality of Teixeira de Freitas, in the extreme south of Bahia.

\begin{tabular}{|c|c|c|c|c|c|c|c|c|c|c|c|}
\hline Data & $\begin{array}{l}\text { Max } \\
\text { Rain }\end{array}$ & $\begin{array}{l}\text { Total } \\
\text { Rain }\end{array}$ & $\mathrm{EI}_{30}$ & $\begin{array}{l}\text { I ave- } \\
\text { rage }\end{array}$ & $\begin{array}{c}\mathrm{I} \\
\max \end{array}$ & $\begin{array}{c}\text { Total } \\
\mathrm{Ke}\end{array}$ & Peak & $\begin{array}{c}\text { Dura- } \\
\text { tion }\end{array}$ & Pattern & Soil loss & $\begin{array}{c}\text { P5 } \\
\text { days }\end{array}$ \\
\hline & \multicolumn{2}{|c|}{----mm---- } & MJ mm ha- ${ }^{-1} h^{-1}$ & \multicolumn{2}{|c|}{---mm h ${ }^{-1}---$} & $\mathrm{MJ} \mathrm{ha}^{-1}$ & \multicolumn{2}{|c|}{-------h------- } & & $\mathrm{Mg} \mathrm{ha}^{-1}$ & $\mathrm{~mm}$ \\
\hline $9 / 5 / 13$ & 2.0 & 12.4 & 14.6 & 2.3 & 12.0 & 2.0 & 24.2 & 38.3 & Del. & 65.3 & 24.2 \\
\hline $7 / 2 / 13$ & 1.8 & 15.0 & 15.6 & 2.3 & 10.8 & 2.4 & 4.5 & 20.5 & Av. & 0.4 & 0.6 \\
\hline $1 / 8 / 14$ & 7.2 & 37.2 & 283.3 & 7.7 & 43.2 & 8.3 & 8.0 & 12.0 & Del. & 15.8 & 10.6 \\
\hline $1 / 20 / 13$ & 8.8 & 32.4 & 254.6 & 7.5 & 52.8 & 7.2 & 2.0 & 9.0 & Av. & 48.6 & 17.2 \\
\hline $8 / 18 / 13$ & 3.6 & 42.0 & 108.3 & 3.7 & 21.6 & 7.7 & 17.2 & 44.3 & Del. & 7.0 & 3.6 \\
\hline $3 / 28 / 13$ & 3.0 & 37.4 & 105.1 & 4.0 & 18.0 & 7.1 & 10.2 & 39.2 & Av. & 1.5 & 1 \\
\hline $2 / 24 / 14$ & 5.0 & 10.6 & 39.8 & 7.9 & 30.0 & 2.3 & 2.2 & 5.2 & Int. & 37.9 & 51 \\
\hline $7 / 24 / 13$ & 2.2 & 23.8 & 41.7 & 3.2 & 13.2 & 4.2 & 5.0 & 24.2 & Av. & 1.3 & 1.8 \\
\hline $11 / 26 / 12$ & 5.2 & 22.6 & 72.5 & 4.7 & 31.2 & 4.8 & 0.2 & 19.3 & Av. & 0.3 & 1.8 \\
\hline $17 / 12 / 13$ & 4.2 & 16.4 & 73.8 & 5.5 & 25.2 & 3.4 & 1.2 & 6.5 & Av. & 22.2 & 140.8 \\
\hline $10 / 7 / 13$ & 3.0 & 21.8 & 52.7 & 5.4 & 18.0 & 4.2 & 5.2 & 5.3 & Del. & 1.4 & 25.8 \\
\hline $10 / 31 / 13$ & 2.8 & 24.0 & 53.2 & 3.5 & 16.8 & 4.4 & 23.2 & 38.8 & Int. & 0.3 & 12.2 \\
\hline
\end{tabular}

Rain: Rainfall; I .: Intensity; Ke: Kinetic Energy; Av: Advanced; Int: Intermediate; Del .: Delayed; P5 days: rainfall of the 5 days prior to the event. 
Figure 10. Correlation between rainfall patterns and soil loss in Caravelas, in the extreme south of Bahia.

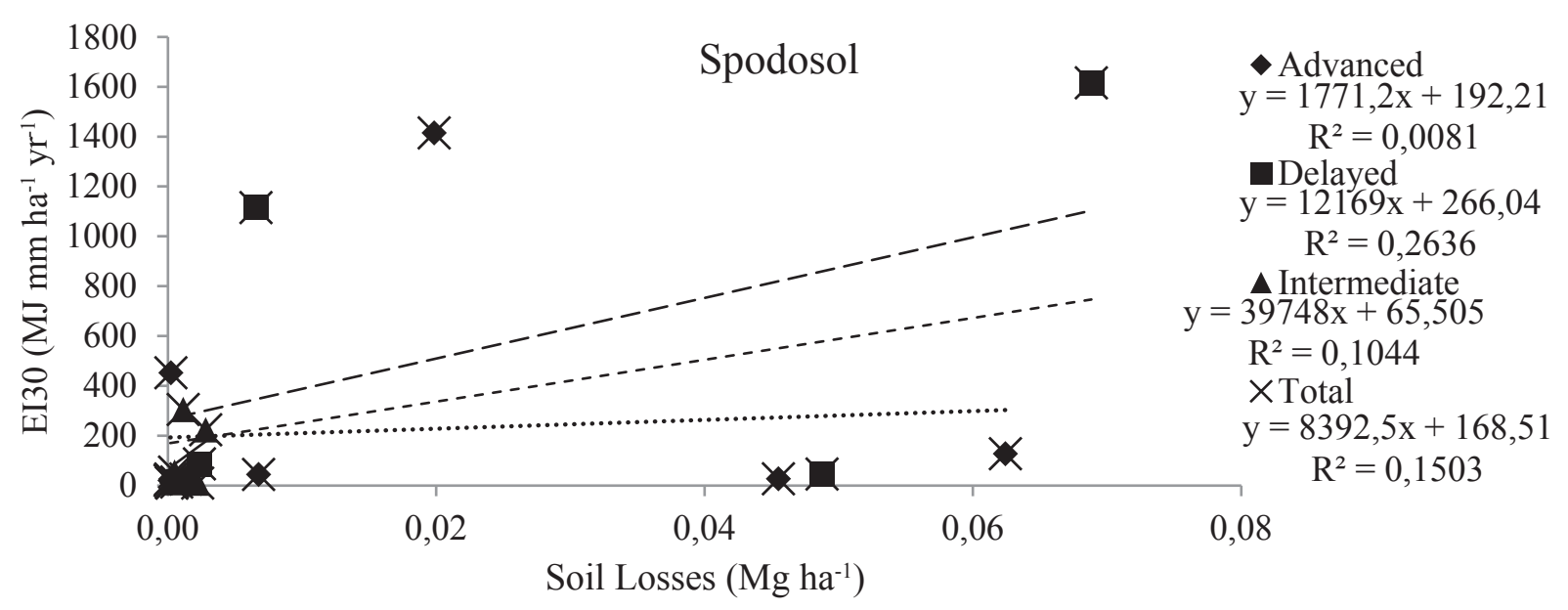

The presentresults show that not only erosivity, but also soil attributes, slope, slope shape, soil moisture, and rainfall patterns influence soil and water losses by water erosion. Finally, the interpretation of water erosion requires a multifaceted approach.

\section{Conclusions}

The area of Teixeira de Freitas, with Argisol, presented high soil and water losses, totaling 686.85 $\mathrm{Mg} \mathrm{ha}^{-1}$ and $1021.51 \mathrm{~mm}$, respectively, when considering the three treatments. Conversely, Caravelas area, with Spodosol, soil and water losses were very low, totaling $0.42 \mathrm{Mg} \mathrm{ha}^{-1}$ and $33.36 \mathrm{~mm}$, respectively.

Wood mean annual increment in the Argisol area, where the highest soil losses occurred, was lower $\left(27.9 \mathrm{~m}^{3} \mathrm{ha}^{-1}\right.$ year $\left.^{-1}\right)$ than in the Spodosol area (59.63 $\mathrm{m}^{3} \mathrm{ha}^{-1}$ year ${ }^{-1}$ ), reflecting the erosion-productivity interdependence of eucalyptus.

Eucalyptus minimum tillage was efficient in reducing soil and water losses by water erosion.

The advanced pattern was predominant in both areas.

Slope shape and soil moisture greatly influenced soil and water losses.

\section{Acknowledgements}

To the Suzano Papel \& Celulose Company, for authorizing the experimental areas and for the logistics and financial support. To Capes, FAPEMIG (processes PPM 00422-13 and CAGAPQ01053-15) and CNPq (cases 305010/2013 -1 and 471522 / 2012-0) for the financial support.

\section{References}

ALVARES, C. A.; STAPE, J. L.; SENTELHAS, P. C.; GONÇALVES, J. L. M.; SPAROVEK, G. Köppen's climate classification map for Brazil. Meteorologische Zeitschrift, Stuttgart, v. 22, n. 6, p. 711-728, 2013.

ANACHE, J. A. A.; WENDLAND, E. C.; OLIVEIRA, P. T. S.; FLANAGAN, D. C.; NEARING, M. A. Runoff and soil erosion plot-scale studies under natural rainfall: a meta-analysis of the Brazilian experience. Catena, Amsterdam, v. 152, p. 29-39, 2017.

AQUINO, R. F.; SILVA, M. L. N.; FREITAS, D. A. F.; CURI, N.; AVANZI, J. C. Soil losses from Typic Cambisols and Red Latosol within three different erosive rainfall patterns. Revista Brasileira de Ciência do Solo, Viçosa, MG, v. 37, n. 5, p. 213-220, 2013.

BAZZANO, M. G. P.; ELTZ, F. L. F.; CASSOL, E. A. Erosividade e características hidrológicas das chuvas de Rio Grande (RS). Revista Brasileira de Ciência do Solo, Viçosa, MG, v. 34, n. 1, p. 235-244, 2010. 
BERTONI, J.; LOMBARDI NETO, F. Conservação do solo. 8. ed. São Paulo: Editora Ícone, 2012. 355 p.

CABEDA, M. S. V. Computation of storm EI values. West Lafayette: Purdue University, 1976. 6 p.

CÂNDIDO, B. M.; SILVA, M. L. N.; CURI, N.; BATISTA, P. V. G. Erosão hídrica pós-plantio em florestas de eucalipto na bacia do rio Paraná, no leste do Mato Grosso do Sul. Revista Brasileira de Ciência do Solo, Viçosa, MG, v. 38, n. 5, p. 1565-1575, 2014.

CÂNDIDO, B. M.; SILVA, M. L. N.; CURI, N.; FREITAS, D. A. F.; MINCATO, R. L.; FERREIRA, M. M. Métodos de indexação de indicadores na avaliação da qualidade do solo em relação à erosão hídrica. Revista Brasileira de Ciência do Solo, Viçosa, MG, v. 39, n. 2, p. 589-597, 2015.

CARDOSO, D. P.; SILVA, M. L. N.; CARVALHO, G. J.; FREITAS, D. A. F.; AVANZI, J. C. Plantas de cobertura no controle das perdas de solo, água e nutrientes por erosão hídrica. Revista Brasileira de Engenharia Agrícola e Ambiental, Campina Grande, v. 16, n. 6, p. 632-638, 2012.

CARVALHO FILHO, A.; CURI, N.; FONSECA, S. Sistema informatizado e validado de avaliação da aptidão silvicultural das terras dos tabuleiros costeiros brasileiros para eucalipto. Lavras: Editora UFLA, 2013. $138 \mathrm{p}$.

CASSOL, E. A.; MARTINS, D.; ELTZ, F. L. F.; LIMA, V. S.; BUENO, A. C. Erosividade e padrões hidrológicos das chuvas de Ijuí (RS) no período de 1963 a 1993. Revista Brasileira de Agrometeorologia, Piracicaba, v. 15, n. 3, p. 220-231, 2007.

COGO, N. P. Uma contribuição à metodologia de estudo das perdas por erosão em condições de chuva natural. Alguns conceitos básicos e modelos de uma ficha para registro das características da chuva e perdas de solo e água ( $1^{\text {a }}$ aproximação). In: ENCONTRO NACIONAL DE CONSERVAÇÃO DO SOLO, 2., 1978, Passo Fundo. Anais... Passo Fundo: Embrapa, CNPT, 1978. p. 99-107.

CURI, N.; KER, S. C. Levantamento pedológico de áreas da Aracruz Celulose S. A. nos estados do Espírito Santo, Bahia e Minas Gerais, e sua interpretação para o cultivo do eucalipto e para o ambiente em geral. Aracruz: ARCEL, 2004. CD-ROM.

ELTZ, F. L. F.; CASSOL, E. A.; PASCOTINI, P. B.; AMORIM, R. S. S. Potencial erosivo e características das chuvas de São Gabriel, RS, de 1963 a 1993. Revista Brasileira de Engenharia Agrícola e Ambiental, Campina Grande, v. 17, n. 6, p. 647-654, 2013.

EMPRESA BRASILEIRA DE PESQUISA AGROPECUÁRIA - EMBRAPA. Manual de métodos de análise de solo. Centro Nacional de Pesquisa de Solos. 2. ed. Rio de Janeiro: EMBRAPA, 1997. 212 p.

Sistema brasileiro de classificação de solos. 3 . ed. Rio de Janeiro: EMBRAPA, 2013. 353 p.

HORNER, W. W.; JENS, S. W. Surface runoff determination from rainfall without using coefficients. Transactions of the American Society of Civil Engineers, New York, v. 107, n. 1, p. 1039-1117, 1942.

MANNIGEL, A. R.; CARVALHO, M. P.; MORETI, D.; MEDEIROS, L. R. Fator erodibilidade e tolerância de perda dos solos do Estado de Sã o Paulo. Acta Scientiarum, Maringá, v. 24, n. 5, p. 1335-1340, 2002.

MARTINS, S. G.; SILVA, M. L. N.; AVANZI, J. C.; CURI, N.; FONSECA, S. Fator cobertura e manejo do solo e perdas de solo e água em cultivo de eucalipto e em Mata Atlântica nos Tabuleiros Costeiros do estado do Espírito Santo. Scientia Forestalis, Piracicaba, v. 38, n. 87, p. 517-526, 2010.

MAZURANA, J.; CASSOL, E.; SANTOS, L. C.; ELTZ, F. L. F.; BUENO, A. C. Erosividade, padrões hidrológicos e período de retorno das chuvas erosivas de Santa Rosa (RS). Revista Brasileira de Engenharia Agrícola e Ambiental, Campina Grande, v. 13, p. 975983, 2009. Suplemento.

OLIVEIRA, A. H.; SILVA, M. L. N.; CURI, N.; AVANZI, J. C.; KLINKE NETO, G.; ARAÚJO, E. F. Water erosion in soils under eucalyptus forest as affected by development stages and management systems. Ciência e Agrotecnologia, Lavras, v. 37, n. 2, p. 159-169, 2013 a.

OLIVEIRA, L. C.; BERTOL, I.; CAMPOS, M. L.; MECABÔ JÚNIOR, J. Erosão hídrica em plantio de pinus, em estrada florestal e em campo nativo. Revista Floresta, Curitiba, v. 44, n. 2, p. 239-248, 2014.

OLIVEIRA, P. T. S.; WENDLAND, E.; NEARING, M. A. Rainfall erosivity in Brazil: a review. Catena, Amsterdam, v. 100, p. 139-147, 2013b.

PINHEIRO, A.; KAUFMANN, V.; SCHNEIDERS, D.; GOTARDO, R. Transporte de sedimentos e espécies químicas em áreas de reflorestamentos e pastagem com base em chuva simulada. Revista Ambiente e Água, Taubaté, v. 8, n. 2, p. 109-123, 2013.

RESENDE, M.; CURI, N.; REZENDE, S. B.; CORRÊA, G. F.; KER, J. C. Pedologia base para distinção de ambientes. Lavras: Editora UFLA, 2014. 378 p.

RIBEIRO, A. S.; MINCATO, R. L.; CURI, N.; KAWAKUBO, F. S. Vulnerabilidade ambiental à erosão hídrica em uma sub-bacia hidrográfica pelo processoanalítico hierárquico. Revista Brasileira de Geografia e Física, Recife, v. 9, n. 1, p. 16-31, 2016. 
ROSA, A. G.; SOUSA, A. M. L.; COSTA, J. A.; SOUZA, E. B. Erosividade da chuva em Rondon do Pará, PA, Brasil de 1999 a 2015 e projetada para 2035. Revista Ambiente e Água, Taubaté, v. 11, n. 4, p. 1006-1021, 2016.

SILVA, M. A.; SILVA, M. L. N.; CURI, N.; AVANZI, J. C.; LEITE, F. P. Sistemas de manejo em plantios florestais de eucalipto e perdas de solo e água na região do Vale do Rio Doce, MG. Ciência Florestal, Santa Maria, v. 21, n. 4, p. 765-776, 2011.

SPERANDIO, H. V.; CECÍLIO, R. A.; CAMPANHARO, W. A.; DEL CARO, C. F.; HOLLANDA, M. P. Avaliação da erosão hídrica pela alteração na superfície do solo em diferentes coberturas vegetais de uma sub-bacia hidrográfica no Município de Alegre, ES. Semina: Ciências Agrárias, Londrina, v. 33, n. 4, p. 14111418,2012 .

TRINDADE, A. L. F.; OLIVEIRA, P. T. S.; ANACHE, J. A. A.; WENDLAND, E. Variabilidade espacial da erosividade das chuvas no Brasil. Pesquisa Agropecuária Brasileira, Brasília, v. 51, n. 12, p. 1918-1928, 2016.
VALIM, W. C.; PANACHUKI, E.; PAVEI, D. S.; ALVES SOBRINHO, T.; ALMEIDA, W. S. Effect of sugarcane waste in the control of interrill erosion. Semina: Ciências Agrárias, Londrina, v. 37, n. 3, p. 1155-1164, 2016.

VALLADARES, G. S.; GOMES, A. S.; TORRESAN, F. E.; RODRIGUES, C. A. G.; GREGO, C. R. Modelo multicritério aditivo na geração de mapas de suscetibilidade à erosão em área rural. Pesquisa Agropecuária Brasileira, Brasília, v. 47, n. 9, p. 13761383, 2012.

WANG, W.; YIN, S.; XIE, Y.; LIU, B.; LIU, Y. Effects of four storm patterns on soil loss from five soils under natural rainfall. Catena, Amsterdam, v. 141, p. 56-65, 2016.

WISCHMEIER, W. H.; SMITH, D. D. Predicting rainfall erosion losses: a guide to conservation planning. Washington: USDA, 1978. 58 p. (Agricultural Handbook, 537). 